\title{
ANALISIS KESALAHAN SISWA SMK KELAS XI PADA MATERI LOGIKA MATEMATIKA
}

\author{
Wulan Yuni Sawitri \\ Program Studi Pendidikan Matematika, IKIP SILIWANGI \\ Email:wulansawitri16@gmail.com
}

\begin{abstract}
Abstrak:
Penelitian ini bertujuan untuk menganalisis kesalahan siswa SMK kelas XI pada materi logika matematika. Metode yang digunakan adalah metode deskripsi kualitatif. Pengambilan sampel untuk penelitian dilakukan secara purposive sampling adapun siswanya ialah siswa SMK kelas XI dengan jumlah siswa 32 orang. Soal tes yang diberikan berupa 4 soal uraian. Hasil penelitian menunjukan dari 3 indikator yang terdapat pada soal hanya 1 indikator yang memiliki kriteria data baik sedangkan sisanya memiliki kriteria data kurang dan kurang sekali ini disebabkan karena kurang telitinya siswa ketika membaca soal, kurangnya pemahaman materi logika serta kurangnya siswa dalam latihan-latihan soal logika yang menyebabkan siswa kesulitan ketika mengerjakan soal logika ini.
\end{abstract}

Kata Kunci: Analisis Kesalahan, Logika Matematika

\section{Pendahuluan}

Setiap manusia yang ada di muka bumi ini wajib mendapatkan pendidikan yang layak. Pendapat ini sejalan dengan Chotimah (Niasih, Romlah, \& Zhanty, 2019) Pendidikan merupakan pembelajaran paling mendasar yang wajib setiap individu dapatkan baik secara normal maupun informal. Pendidikan wajib diberikan dari sejak dini. Tujuan pendidikan nasional yang tercantum pada pasal 3 UU RI No.20 tahun 2003 (Junaidi, 2018) "Pendidikan nasional berfungsi mengembangkan kemampuan dan membentuk watak serta perdaban bangsa yang bermartabat dalam rangka mencerdaskan kehidupan bangsa, bertujuan untuk berkembangnya potensi peserta didik agar menjadi manusia yang beriman dan bertakwa kepada Tuhan Yang Maha Esa, berakhlak mulia, sehat, berilmu, cakap, kreatif, mandiri, dan menjadi warga Negara yang demokratis serta bertanggung jawab.”.

Kualitas pendidikan di Indonesia tergolong rendah, pendapat ini sejalan dengan hasil penelitian yang dilakukan oleh Trend In International Matematics and Sciense Study (TIMSS), dimana TIMSS merupakan lembaga yang mengukur serta membandingkan kemampuan matematis siswa-siswi antar negara, dengan penguasaan matematika siswa tingkat 8. Dimana pada tahun 1999 hasil penelitian dari TIMSS Indonesia berada pada peringkat 6 terendah yakni peringkat 32 dari
38 negara yang diteliti, kemudian pada tahun 2003 TIMSS melakukan penelitian kembali dengan menambah 7 subyek penelitian menjadi 45 subyek, hasil dari penelitian ini terlihat bahwa Indonesia berada pada peringkat 9 terendah dari 45 negara yang diteliti, sedangkan pada tahun 2007 TIMSS melakukan kembali penelitian dengan jumlah subyek yakni 48 subyek, hasil dari penelitian pada tahun 2007 mengemukakan bahwa Indonesia berada pada peringkat 7 terendah yakni peringkat 41 dari 48 negara yang diteliti. Dari tiga hasil penelitian yang dilakukan oleh TIMSS pada beberapa tahun silam ditemukan bahwa rata-rata skor yang diperoleh oleh siswa-siswi yang ada di Indonesia adalah 397, skor ini masih jauh dibawah skor Internasional yaitu 500 (Khadijah, Maya, \& Setiawan, 2018).

Menurut BSNP (Kurniati, Pujiastuti, \& Kurniasih, 2017) Matematika merupakan ilmu pengetahuan yang dipelajari pada setiap jenjang pendidikan karena memiliki peran penting untuk membentuk manusia berkualitas baik. Melalui pembelajaran matematika, peserta didik diharapkan memiliki kemampuan berpikir logis, analitis, sistematis, kritis dan kreatif serta memiliki kemampuan bekerja sama. Sejalan dengan pendapat tersebut, Chotimah (Andriawan, Setiawati, Sari, \& Chotimah, 2018) mengatakan "Mathematics is an important part that 
cannot be separated from human life" maksudnya Matematika merupakan bagian yang sangat penting yang tidak dapat dipisahkan dari kehidupan manusia, sehingga matematika perlu diperkenalkan sejak dini. Lebih lanjut Uno (Farida, 2015) mengemukakan bahwa matematika merupakan alat pikir serta alat yang dapat memberikan solusi untuk berbagai persoalan praktis yang didalamnya membutuhkan analisis serta logika berpikir seseorang.

Berdasarkan Kurikulum 13, salah satu pokok bahasan matematika yang disajikan di SMK kelas XI yaitu Logika matematika. Mempelajari materi logika matematika sangatlah penting, karena dapat melatih siswa untuk berpikir secara tepat dan logis untuk memahami peristiwa yang terjadi dalam kehidupan sehari-hari.

Namun materi logika matematika pada kenyataannya masih merupakan materi yang sulit bagi siswa, sebagaimana yang dikemukakan oleh Nurcholis (Lapohea, 2014), bahwa lemahnya pemahaman siswa tentang konsep-konsep atau prinsip dalam matematika menyebabkan siswa sulit mempelajari materi logika matematika. Ini disebabkan karena siswa beranggapan bahwa matematika itu sulit dan menakutkan.

Berdasarkan latar belakang di atas, maka peneliti ingin mengetahui sejauh mana kemampuan siswa terhadap materi logika matematika dengan cara menganalisis kesalahan-kesalahan siswa SMK kelas XI pada materi logika matematika.

\section{Metode Penelitian}

Pengumpulan data ini menggunakan pendekatan kualitatif dengan metode deskriptif. Mulyadi (Rahmawati \& Zhanty, 2019) mengatakan bahwa penelitian deskriptif bertujuan untuk menggambarkan variabel yang berkenaan dengan masalah yang diteliti dengan menghubungkan gejala kenyataan sosial yang terjadi. Sedangkan menurut Sugiyono (Puspitasari, Muliawanti, Gunawan, \& Sairan, 2019) mengatakan bahwa metode penelitian kualitatif ialah metode penelitian yang digunakan untuk meneliti kondisi obyek yang alamiah, dimana peneliti sebagai instrument kunci, teknik pengambilan data yang dilakukan ialah secara gabungan serta analisis data bersifat induktif, dan hasil penelitian kualitatif ini lebih menekankan makna dari pada generalisasi. Populasi dan sampel penelitian ini adalah siswa kelas XI pada semester ganjil di SMKN 1 Cimahi yang berjumlah 32 orang, pengambilan sampel untuk penelitian dilakukan secara purposive sampling.

Langkah-langkah penelitian ini dibagi menjadi tiga tahap yaitu: (1). Persiapan, yaitu mengkaji permasalahan, menyusun latar belakang dan landasan teori, mempersiapkan instrument penelitian, menguris perizinan dan menentukan jadwal penelitian; (2). Pelaksanaan, yaitu memberikan tes mengenai logika matematika; (3). Evaluasi, yaitu mengumpulkan, mengolah, menganalisis dan menyimpulkan data hasil penelitian.

Adapun soal yang diberikan adalah 4 butir pertanyaan dengan materi logika matematika dalam bentuk uraian. Sebelum digunakan dalam penelitian soal tersebut telah diuji validitas, daya pembeda dan indeks kesukaran. Skala keseluruhan pemberian skor terhadap jawaban siswa dikonversi dalam bentuk nilai skala (1-100), dengan menafsirkan data sesuai kriteria pemahaman menurut Arikunto (Khadijah et al., 2018), batasan tersebut terdapat dalam Tabel 1:

Tabel 1. Kriteria Data

\begin{tabular}{cc}
\hline Persentase & Kriteria \\
\hline $81 \%-100 \%$ & Baik Sekali \\
$61 \%-80 \%$ & Baik \\
$41 \%-60 \%$ & Cukup \\
$21 \%-40 \%$ & Kurang \\
$0 \%-20 \%$ & Kurang Sekali \\
\hline
\end{tabular}




\section{Hasil dan Pembahasan}

Setelah siswa diberikan tes logika matematika maka peneliti menganalisa jawaban siswa satu persatu berdasarkan kriteria data yang dikemukakan oleh Arikunto (Khadijah et al., 2018). Data tersebut kemudian dianalisis oleh peneliti secara deskriptif. Nilai siswa dikonversikan dengan skala (1-100). Kemudian di pilah antara siswa yang menjawab benar perbutir soal dengan siswa yang menjawab salah perbutir soal yang diperoleh hasil seperti pada
Tabel
2.

Tabel 2 . Persentase Siswa Menjawab Benar Perbutir Soal

\begin{tabular}{lcc}
\hline \multicolumn{1}{c}{ Indikator } & No. Soal & Persentase \\
\hline $\begin{array}{l}\text { Mampu mencetuskan banyak gagasan, jawaban, } \\
\text { penyelesaian masalah atau pertanyaan }\end{array}$ & 1 & $28,1 \%$ \\
& 2 & $65.6 \%$ \\
$\begin{array}{l}\text { Mampu memperkaya dan mengembangkan suatu } \\
\text { gagasan/produk. Menambah atau merinci detail- }\end{array}$ & 3 & $0 \%$ \\
$\begin{array}{l}\text { detail dari suatu objek gagasan atau situasi objek, } \\
\text { gagasan/situasi menjadi lebih menarik. }\end{array}$ & & \\
$\begin{array}{l}\text { Mampu membuat kombinasi-kombinasi yang } \\
\text { tidak lazim dan bagian-bagian atau unsur. }\end{array}$ & 4 & $34.4 \%$ \\
\hline
\end{tabular}

Berdasarkan tabel di atas dari 3 indikator hanya terdapat 1 indikator yang masuk kriteria baik yaitu indikator mampu mencetuskan banyak gagasan, jawaban, penyelesaian malasalah atau pertanyaan dengan tingkat persentase sebesar $65.6 \%$ pada soal no 2, untuk soal no 1 masuk kedalam kriteria kurang dengan persentase $28.1 \%$. Sedangkan 2 indikator lainnya masuk kedalam kriteria kurang,yaitu: indikator mampu memperkaya dan mengembangkan suatu gagasan/produk. Menambah atau merinci detail-detail dari suatu objek, gagasan/situasi menjadi lebih menarik dengan persentase $0 \%$. Serta indikator mampu membuat kombinasikombinasi yang tidak lazim dan bagianbagian atau unsur dengan tingkat persentase $34.4 \%$. Berikut ini pembahasan setiap soal logika matematika.

Soal no 1: Siska adalah seorang siswa yang berprestasi disekolahnya, dia ditunjuk oleh sekolah untuk menjadi calon Duta Remaja 2019 sebagai perwakilan dari sekolah. Siska harus menjalani tes dan karantina untuk menjadi Duta Remaja 2019. Tes dilaksanakan selama 5 hari senin-jum'at. Disisi lain siska sebagai siswa harus mengikuti ulangan Bahasa Indonesia pada hari kamis. a. Susunlah pernyataan tersebut kedalam pernyataan $\quad p \rightarrow q \quad$ (cetuskan kemungkinan keputusan yang diambil oleh Siska)!

b. Indentifikasikan sah atau tidaknya pernyataan tersebut kedalam tabel kebenaran!

Pada soal no 1 ini siswa diharapkan mampu mencetuskan banyak gagasan, jawaban, penyelesaian masalah atau pertanyaan.

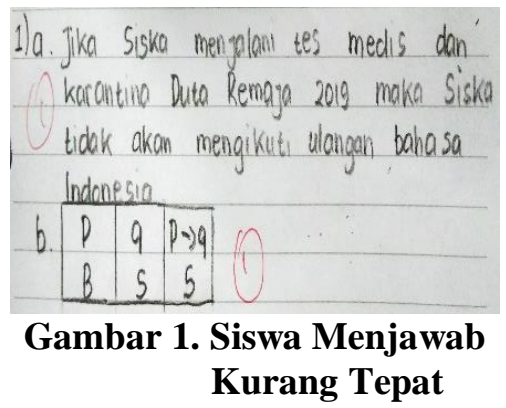

Pada Gambar 1 terlihat bahwa jawaban siswa kurang tepat ini dikarenakan siswa hanya mencetuskan satu kemungkinan yang akan diambil oleh Siska tanpa ada kemungkinan lain yang dapat diambil, serta identifikasi sah atau tidaknya pada tabel kebenaran hanya satu pernyataan saja yang dicantumkan sedangkan dalam tabel kebenaran minimal harus ada empat 
pernyataan untuk membuktikan sah atau tidaknya pernyataan tersebut.

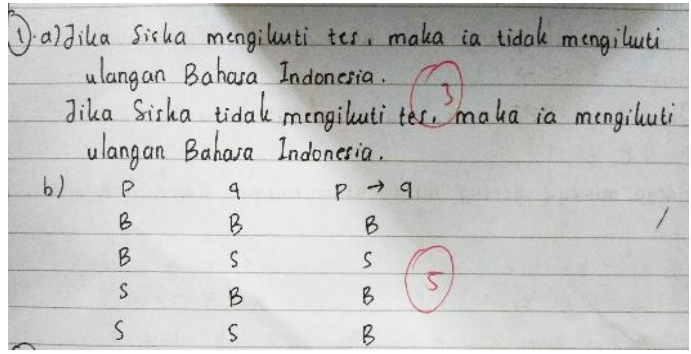

Gambar 2. Jawaban Siswa Hampir Tepat

Pada Gambar 2 terlihat bahwa jawaban siswa hampir tepat ini dikarenakan siswa membuat 2 kemungkinan pernyataan keputusan yang akan diambil oleh Siska, kemungkinan pertama "Jika Siska mengikuti tes maka ia tidak megikuti ulangan bahasa Indonesia" kemungkina ke dua "Jika Siska tidak mengikuti tes maka ia mengikuti ulangan bahasa Indonesia" serta membuat tabel kebenaran dengan lengkap untuk identifikasi sah atau tidaknya pernyataan tersebut.

Jawaban pada Gambar 1 dan 2 belum tepat dikarenakan, seharusnya siswa membuat 4 kemungkinan yang akan diambil oleh Siska serta membuat tabel kebenaran dari empat pernyataan untuk mengidentifikasi sah atau tidaknya kemungkinan yang akan diambil oleh Siska.

Soal no 2 : Pilihlah satu pernyataan dari soal no 1 kemudian susunlah dalam bentuk $p$ dan $q$ kemudian nyatakan kedalam konvers, invers dan kontraposisinya!

Pada soal no 2 ini siswa diharapkan mampu mencetuskan banyak gagasan, jawaban, penyelesaian masalah atau pertanyaan.

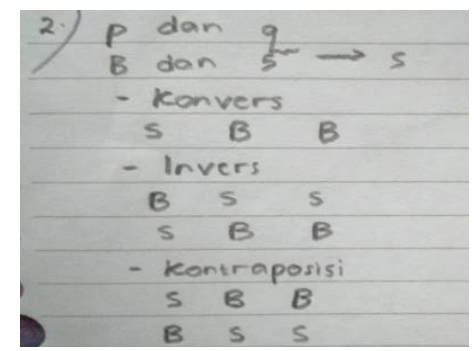

Gambar 3. Jawaban Siswa Kurang Tepat
Pada Gambar 3 terlihat bahwa jawaban siswa kurang tepat ini dikarenakan siswa hanya membuat tabel kebenarannya saja untuk konvers, invers dan kontraposisi tanpa disertai kalimat penyataan yang akan dibentuk kedalam konvers, invers serta kontraposisinya yang mengakibatkan jawaban siswa tidak sesuai dengan perintah dari soal no 2 serta mebuat jawaban siswa menjadi rancu.

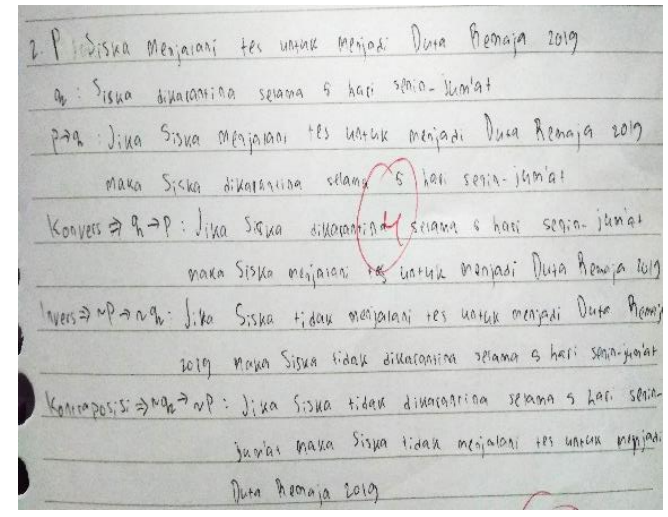

Gambar 4. Jawaban Siswa Benar

Pada Gambar 4 terlihat bahwa siswa menjawab benar, dengan diawali adanya kalimat pernyataan $\mathrm{p}$ : "Siska menjalani tes selama menjadi Duta Remaja 2019" dan q: "Siska dikarantina selama 5 hari senin-jumat" serta adanya kalimat implikasi $p \rightarrow q$ : " Jika Siska menjalani tes untuk menadi Duta Remaja 2019 maka Siska dikarantina selama 5 hari seninjumat", pada gambar ini juga terlihat bahwa siswa memberikan informasi terlebih dahulu apa itu konvers, invers serta kontraposisi setelah itu barulah siswa membuat kalimat dalam bentuk konvers, invers serta kontraposisinya.

\section{Soal no 3 :}

Perhatikan pernyataan $p$ dibawah ini: $p$ : "Harga minyak goreng naik"

Tentukan pernyataan $q$ dan $r$ sehingga membentuk sebuah argumen

$$
\begin{gathered}
\text { Premis } 1: p \vee q \\
\text { Premis } 2: \sim q \rightarrow r \\
\therefore p \vee \sim r
\end{gathered}
$$

Periksalah sah atau tidaknya argumen tersebut!

Pada soal no 3 ini siswa diharapkan mampu memperkaya dan mengembangkan suatu gagasan/produk. Menambah atau merinci 
detail-detail dari suatu objek gagasan atau situasi objek, gagasan/situasi menjadi lebih menarik.

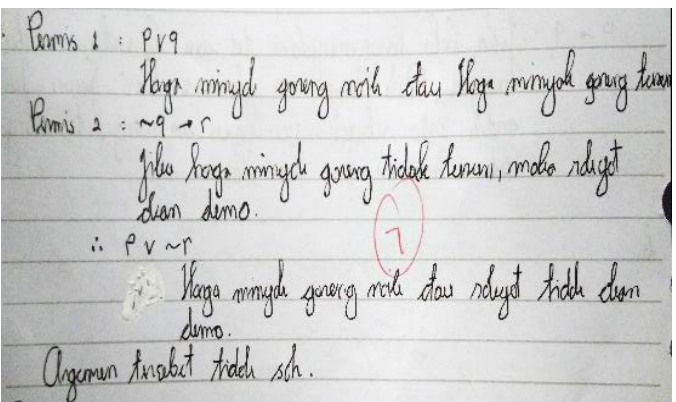

\section{Gambar 5. Jawaban Siswa Kurang Tepat}

Pada Gambar 5 terlihat jawaban siswa kurang tepat, karena siswa hanya menentukan pernyataan q: " Harga minyak goreng turun" dan r: "Rakyat demo" serta hanya membuat kesimpulannya saja tanpa membuat tabel kebenaran untuk menguji sah atau tidaknya argument yang telah mereka jawab, serta siswa kurang teliti dan jeli ketika membaca soal, yang mengakibatkan tingkat persentase siswa menjawab benar pada soal ini sangat rendah yaitu $0 \%$. Seharusnya untuk menjawab soal ini siswa harus membuat pernyataan $q$ dan $r$ sehingga membentuk sebuah argument setelah itu siswa harus membuat tabel kebanaran untuk memeriksa sah atau tidaknya argument tersebut.

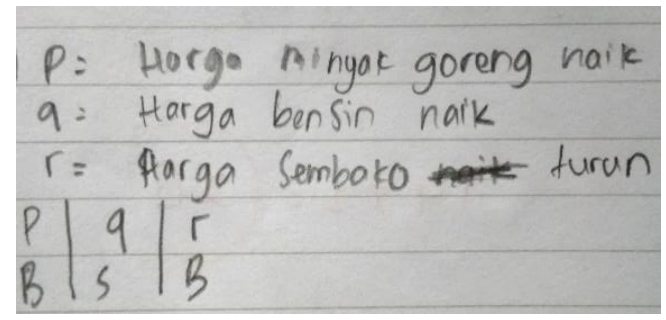

\section{Gambar 6. Jawaban Siswa Tidak Tepat}

Pada Gambar 6 terlihat bahwa jawaban siswa tidak tepat ini dikarenakan siswa hanya menulis pernyataan p: "Harga minyak goreng naik", pernyataan q: "Harga bensin naik" dan pernyataan r: " Harga sembako turun".pada gambar 6 pula terlihat bahwa siswa tidak membuat argument dari tiga pernyataan diatas serta siswa membuat tabel kebenaran yang tidak jelas maksudnya.
Soal no 4 : Susunlah sebuah pernyataan konjungsi beserta ingkarannya. Buktikan sah tidaknya ingkaran dari konjungsi dengan menggunakan tabel kebenaran!

Untuk soal no 4 ini siswa diharapkan Mampu membuat kombinasikombinasi yang tidak lazim dan bagianbagian atau unsur.

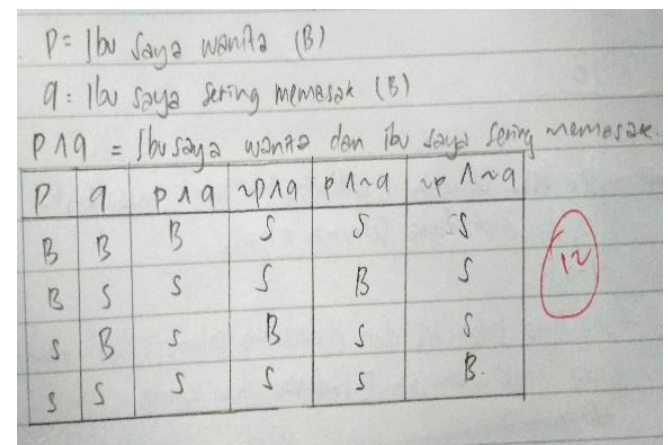

Gambar 7. Jawaban Salah Satu Siswa

Untuk soal no 4 ini siswa diberikan kebebasan untuk menyusun pernyataanpernyataan konjungsi serta ingkarannya yang kemudian dibuktikan kedalam tabel kebenaran seperti pada Gambar 7 terlihat jawaban salah satu siswa, dimana siswa tersebut membuat dua pernyataan yang dapat dilambangkan dengan "p: ibu saya wanita" dan "q: ibu saya sering memasak". Dari dua pernyataan ini dibuat konjungsi yaitu: "Ibu saya wanita dan ibu saya sering memasak". Setelah dibuat konjungsi maka dibuat ingkarannya menjadi "Ibu saya wanita atau ibu saya sering memasak". Untuk membuktikan argumen ini maka siswa membuat tabel kebenaran untuk membuktikan sah atau tidaknya argumen tersebut.

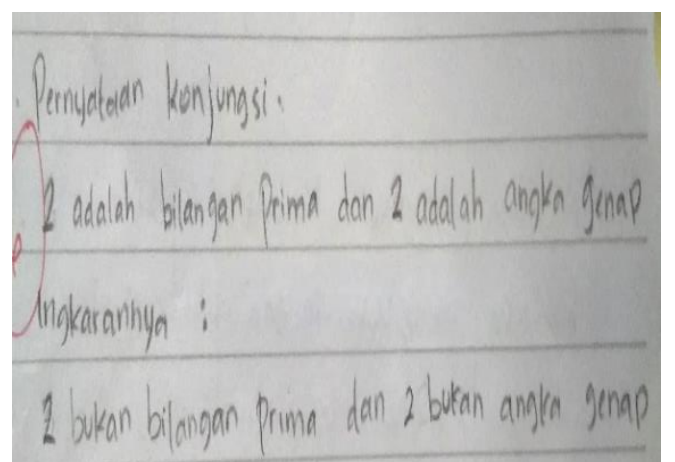

Gambar 8. Jawaban Siswa Kurang Tepat 
Pada Gambar 8 terlihat bahwa jawaban siswa kurang tepat ini disebabkan siswa langsung membuat kalimat konjungsinya, dimana tidak dituliskan mana peryataan satu mana pernyataan dua, serta siswa kurang teliti ketika membaca soal dan ketika menjawab pertnyaan yang dimana siswa diharuskan membuat tabel kebenaran untuk menguji sah atau tidaknya argument tersebut siswa tidak membuat tabel kebenaran.

Secara kesuluruhan dari pembahasan empat soal diatas diketahui bahwa kesalahan siswa terdapat pada kurang telitinya siswa ketika membaca soal, siswa kurang berlatih soal-soal logika serta pemahaman materi yang kurang dikuasai oleh siswa ini dikarenkan materi logika merupakan materi yang abstrak, pendapat ini sejalan dengan penelitian yang dilakukan oleh Romadiastri (Romadiastri, 2012) menurutnya faktor yang menyebabkan mahasiswa mengalami kesalahan dalam menyelesaikan soal-soal logika berdasarkan hasil wawancara yang telah dirangkum yaitu: 1). Mahasiswa tidak menguasai dan memahami konsep-konsep sebelumnya yang digunakan dalam materi yang dipelajari dalam hal ini materi logika, 2). Abstraknya materi logika sehingga mahasiswa merasa malas dan bosan, yang menjadikan minat mahasiswa rendah dalam belajar matematika terutama materi logika, 3). Kurangnya latihan dalam mengerjakan soal-soal logika sehingga kesalahan mahasiswa terutama pada kemampuan penguasaan keterampilan dalam menyelesaikan soal cukup banyak.

\section{Simpulan}

Berdasarkan hasil dan pembahasan yang telah dipaparkan maka dapat disimpulkan bahwa dari dari 4 soal uraian yang telah diberikan kepada siswa yang terdiri dari 3 indikator, hanya 1 indikator yang memiliki kriteria data baik sedangkan sisanya memiliki kriteria data kurang dan kurang sekali. Diketahui bahwa kesalahan siswa terdapat pada kurang telitinya siswa ketika membaca soal, kurangnya pemahaman materi logika serta kurangnya siswa dalam latihan-latihan soal logika ini yang menyebabkan siswa kesulitan ketika mengerjakan soal logika ini.

\section{Daftar Pustaka}

Andriawan, A., Setiawati, A. S., Sari, I. P., \& Chotimah, S. (2018). Analisis kemampuan berpikir kritis matematis siswa smp pada materi pythagoras. JPMI Jurnal Pembelajaran Matematika Inovatif, 1(4), 559-568.

Farida, N. (2015). Analisis Kesalaha Siswa SMP Kelas VIII Dalam Menyelesaikan Masalah Soal Cerita Matematika. Aksioma Jurnal Pendidikan Matematika FKIP Univ.Muhammadiya Metro, 8(2), 42-52.

Junaidi, A. (2018). Meningkatkan Aktivitas Dan Hasil Belajar Siswa Dengan Pembelajaran Kooperatif Tipe Think Pair Share (TPS) Untuk Pokok Bahasan Bangun Ruang Sisi Datar Di Kelas VIII SMPN 1 Pragaan. Jurnal Sigma, 4(1), 1-8.

Khadijah, I. N. A., Maya, R., \& Setiawan, W. (2018). Analisis Kemampuan Komunikasi Matematis Siswa Smp Pada Materi Statistika. JPMI Jurnal Pembelajaran Matematika Inovatif, 1(6), 1095-1104.

Kurniati, I. W., Pujiastuti, E., \& Kurniasih, A. W. (2017). Model Pembelajaran Discovery Learning Berbantuan Smart Sticker untuk Meningkatkan Disposisi Matematik dan Kemampuan Berpikir Kritis Ida. Kreano, Jurnal Matematika KreatifInovatif, 8(2), 109-118.

Lapohea, A. Z. (2014). Penerapan Model Pembelajaran Kooperatif Tipe Two Stay Two Stray untuk Meningkatkan Hasil Belajar Siswa pada Materi Logika Matematika. Jurnal Elektronik Pendidikan Matematika Tadulako, 1(2), 133-145.

Niasih, Romlah, S., \& Zhanty, L. S. (2019). Analisis Kemampuan Komunikasi 
Matematis Siswa Smp Pada Materi Statistika. Journal Cendekia:Jurnal Pendidikan Matematika, 3(2), 266277.

Puspitasari, D., Muliawanti, S., Gunawan, \& Sairan. (2019). Analisis Kemampuan Pemecahan Masalah Matematis Siswa Menggunakan Model Pembelajaran Team Games Tournament SMA Muhammadiyah 1 Purwokerto. Aksioma Jurnal Pendidikan Matematika FKIP Univ.Muhammadiya Metro, 8(1),
83-90.

Rahmawati, C., \& Zhanty, L. S. (2019). Analisis kemamampuan komunikasi siswa menengah terhadap resiliensi matematis. JPMI Jurnal Pembelajaran Matematika Inovatif, 2(3), 147-154.

Romadiastri, Y. (2012). Analisis Kesalahan Mahasiswa Matematika dalam Menyelesaikan Soal- Soal Logika. Phenomenon, 2(1), 75-93. 